\title{
LVI. On the fate and character of the monk Roger Bacon Read before the Literary and Philosophical Society
}

\section{Governor Pownall}

To cite this article: Governor Pownall (1802) LVI. On the fate and character of the monk Roger Bacon Read before the Literary and Philosophical Society, Philosophical Magazine Series 1, 12:48, 327-337, DOI: 10.1080/14786440208676071

To link to this article: http://dx.doi.org/10.1080/14786440208676071

曲 Published online: 18 May 2009.

Submit your article to this journal $\pi$

ЏII Article views: 2

Q View related articles $₫$ 
refult; fo that it feemed deducible from it, that $\frac{1}{3}$ th part of carbon in addition to any quantity of iron was infufficient to form fteel; and, referring to the refult of No. VI., it appeared that even $\frac{:}{2}=$ th part formed a fteel much too foft for the general purpofes of manufacture. This conclufion, however, being at variance with facts I had already eftablifhed upon the formation of caft fteel in common crucibles, was here inadmimible, It was therefore necellary to feck for an explanation of the phænomenon of the charcoal difappearing in clofe veffels, formerly alluded to, before any certain knowledge of the exact quantities of charcoal could be afcertained, which were neceffary to form either caft iron or fteel in veffels made impervious to the air *. I uniformly remarked in the prefent experiments, that when the quantity of charcoal introduced was from $\frac{1}{3}$ th to $\frac{1}{2} \frac{1}{5}$ th the weight of the iron, a portion of glals was conftantly formed upon the furface of the metallic button. The quantity generally increafed as the proportion of charcoal decreafed; fo that, in fome experiments, $300,35 \circ$, and 400 grains of amber-colour glafs was obtained. The upper furface of this glafs was frequently of a pure pearly white colour. In one experiment, where $\frac{1}{7}$ th of charcoal was ufed, I obtained a large quantity of glafs celIular throughout. Each cell was furmounted upon the top with concentric circles of pearly lines, forming a curious and pleafing effect.

Having fully fatisfied myfelf that operations performed in clofe veffels thus prepared were fubject to uncertainty, arifing as well from the formation of glafs as from fome unknown affinity exerted upon the charcoal; and having performed feveral experiments with well filled open crucibles, with charcoal alone, wherein I found little comparative lofs, I performed a very accurate feries of experiments, which thall be forwarded for the next number of the Magrazine.

LVI. On the Fate and Cbaracter of tbe Monk Roger Bacon. By Governor Pownalc. Read before the Literary and Pbilofopbtcal Society, Batbヤ.

$\mathrm{T}$

HERE has been much buftle about learning in the world: every age has had its learning; the produce and growth of a defultory activity of the imagination, according to the fafhion of thinking prevalcnt at the time: whilft the

* This inveftigation will form a feparate paper for July.

+ Communicated by the Atsthor.

$\mathrm{X}_{4}$

flow 
flow filent progrefs of the reafoning power is hardly ever noticed in its operations, and feldom received in its effects when they come forward, becaufe not underftood at the time.

It would be a curious detail were we to enumerate the various fancies and follies which bave been called learning, which have been ftudied and applauded as fuch in every age and every country; but it is at the fame time a humiliating truth, that knowledge, which it thould feem is congenial to the right operation of the human intellect in the inveftigation of truth, has come forward to men but llowly and fparingly, and at epochas of very dittant periods, and at the intervals of very diftant centuries: and what is more humiliating in the hiftory of man is, that, when at any time it appears, it comes into the world as an enfant trouve, and is received as fuch, rather than nurtured by thofe whofe relation to it thould be in practice, as it is in nature, congenial to it. True knowledge is therefore generally either defpifed by the conceit of the learning in fafhion, or more generally fufpected as dangerous; which, indeed, it always is to the falfe and artificial authority which affumes and takes the lead in the world.

It is with pain that I have to notice feveral eminent examples of this melancholy truth in the courfe of my ftating the character and fate of the monk Roger Bacon, who is the fubject of this paper.

When Socrates came forward to the world, the powers of the human mind, abforbed in the falfe learning of Greece, had been employed to propagate the fophiltry and fupport the fophifts of the time, whofe fyftem and bufinefs were to keep mankind from true knowledge by an avowed principle of fuch ignorance as was incapable of attaining truth; the purport of which fyftem was to hold men in a fervile obedience to authority, as thofe who had the command of that anthority thould impofe it. Socrates in his theology taught only thofe truths which had been known to the antient philofophers of Greece, and which they had brought from the eaft. What they affected to conceal he taught openly, fo far as went to eftabliah the knowledge of a moral Jyftem connecting the divine and human nature. Here be was original: this was a new trath brought forward to the world. In this, as it is truly faid of him, he brought down truth from heaven, and eftablithed it on a moral foundation on earth.

As to his manner of teaching, he with great addrefs, in accommodation to the learning of the time, profeffed to comnence in ignorance. But whillt the fophilts led, in fyntheic reafoming, from ignorance to a total incapacity in man for truth; he, commencing his theorem from ftated 
igmorance, proceeded by analytic induction to the eliciting of truth: as the algebraifts haye fince done, from a theorem ftated on an unknown quantity, bringing out the true one. He thus not only brought truth to light by reafon, but by the very mode of his reafoning taught the ufe, the extent, and the right of human reafon. This was fufficient to decide the fate which both the teacher and his doctrines experienced. His doctrines were defpifed, and attempts were made by the wits of the time to ridicule his knowledge $:$ it was reprefented as evolved from the clouds*. But, as truth will ttand the teft of ridicule, nothing remained but to decide by autbority that the truths which he taught were inadmiffible; and they were therefore interdicted i $y$ power: and Socrates himfelf was profecuted and condemned to death as a falle teacher, as a corrupter of men, an heretic, unbeliever, and defpifer of the gods! What is fitll more humiliating to the character of man, the doctrines which he taught, and the truths which he publithed, were perverted where received, and even by his difciples. The homely fimplicity of his doctrines was fophifticated and corrupted, in a line of learning, to ufes perverfive of their nature.

I will not here glance, although it is in my mind's eye, at the fimilar fate of a Divine teacher who came forward in the world to enlighten man, and to inftruct him in his moit effential duty and intereft.

Purfining therefore the fate of Socrates, which is not irrelative to the matter of this paper, I thall proceed to ftate that Plato, his favourite difciple, who was a really great mathematician, and particularly converfant in the analytic process of that fience, and who followed the fteps of induction marked out by Socrates, mixed fo many myttic conceits and theories, that he fublimed and fubtilized truth to a mere learned vifion, fuch as the latter Platonifts afterward taught.

Ariftotle, on the other hand, a diftinguifhed difciple of Plato, converted the knowledge of phyfics, both material and intellectual, into an artificial fystem of axioms, data, and maxims, and formed thereon a logical frame of fynthefis; which gave occafion to his immediate followers and to the Peripatetic fchool to found their learning on the authority of teaching, inftead of being founded on trutb led by experience to knowledge, to the difgrace of human intellect, and the perverfion of true philofophy.

It is lamentable to reflect how many theories and myfte. ries, divine as well as natural, fprang from this foul ground;

* Vide the Nubes Ariftephanis. 
which, like meteors, blazed in the regions of learning for a time, but, like fuch meteors, not deriving from true and permanent light, from proper fources, were foon extinguifhed.

Truth, however, was purfued with great energy, occulto velut arbor in cuo, in the ftudies and labours of thofe few votaries of it who were called mathematicians; and many detached unconnected difcoveries were made, which hardly ventured to thow themfelves, or, where they did, were imputed to magic.

At length, after many ages of darknefs, Ruger Bacon, that great luminary, was born in 1214. He, like another Socrates, in the fpirit of truth, in the analytic line of true knowledge, endeavoured to ftate the Impedimenta fcientice, the Caujas ignorantice, and to remove all the obftructions which thut up the road to truth : he then, explaining by fact and example the Utilitas fcientiarum, advanced, by an experimental inveftigation of nature, and by an analyfis of truth, to his Reftauratio bumani intellectûs, and his Inftauratio fcientice.

Reafoning, however, above the fcale of the learning of the age in which he lived, his doctrines were neither underftood nor received; and, where they could not be repreffed by the learning of the time, they were interdicted by the ruling autbority of it. Although the truths which he difcovered, and endeavoured to difclofe to the world, were liftened to by feveral men of knowledge, and fome of them in power *, and though they were received even by the fupreme t authority, held infallible; yet, by a fin againft the boly fpirit of trutb, they were anacknowledged, and fuffered to languin in obfourity. They, with the teacher, were delivered over to perfecution; truth was extinguifhed, and the difcoverer and teacher imprifoned for the crimes of magic and herefy.

Here again, on the ftage of this world, was truth devoted to filence and darknefs, and the difcoverer and teacher of it thrown back into obfcurity, and his doctrines loft in oblivion, except what ignorance rakes up to memory in difgraceful tales of tradition. The ftream, therefore, of this original fpring, whence the knowledge of latter times derives its fource, ran, like the Rhone, concealed and unknown for three or four centuries; whilf in the mean time various empirics in philofophy, various bafelefs theories, (amidft which the ingenious fables of Defcartes more efpecialty, took the lead and afcendancy in the learning of the world. This ftream, however, like the Rhone, emerged again to light on the face 
of the earth, when its courfe became directed with happier fuccefs, and under more fortunate aufpices, by the energy and fpirit of anotber Bacon, the great lord St. Albans, who, although perhaps an original alfo, was a fecond and more fortunate one; yet even not generally known and acknowledged as fuch till near half a century was elapled from the time in which be wrote.

Although Sir Ifaac Newton had made the chief part of his difcoveries on light and colours, and had written the firft parts of his Treatile on Optics, and, "at the defire of feveral gentlemen of the Royal Society, fent them to the fecretary of that fociety, where they were read in 1675 ; and although the other purts were added about 12 years after; yet to avoid, as he fays, being engaged in difputes about thefe matters, he delayed the printing and publifhing of them to 1704 ; and would ftill have delayed, had not the importunity of fome friends overcome the repreffion which he experienced from the jealoufy of fome authoritative leaders." Such is the invariable fpirit and temper of man even in an enlightened age, and fuch is the unavoidable fate of thofe who would enlighten and affitt the knowledge of the world. Such, at leaft, were the feelings of this great and humble fpirit; fuch was his conviction, that the age in which he firft made his difcoveries was neither willing to receive nor capable of poffeffing them, to the purpofe of truth, that the world might have been deprived of them for ever, as in fact it is at this moment of fome difcoveries which he had in view and in purfuit, but which he ceafed to follow up, and has fuggefted only in queries. What a lofs to mankind that thefe fuggeftions, except in fome particular inftances, have not been purfued! For, whatever and howfoever great the difcoveries which have been brought forward by the new philofophic chemifts may be; yet thefe important fuggeftions would, as they have done in fome inftances where they have been taken up, have led to great and interefting philofophic facts hardly at prefent conceivable.

It was from the fame opinion of the temper and want of qualification in that age, perhaps alfo from an oppreffion of fpirit which he felt, that on annther occafion, when confulted by Dr. Bentley, at the time of his being appointed to preach the Boyle's lectures, Sir Ifaac fays in his letter, "There is yet another argument in proof of the Deity, which $I$ take to be a very ftrong one; but until the principles on which it is grounded are better received, I think it more advifeable to let it fleep." Such has ever been the fate of knowledge, buth to the difcoverers and to truth itfelf, on its firt 
appearances amongtt thofe who hold the lead of learning. Shall we then wonder at the fate which this true and real philofopher, the monk Roger Bacon, experienced in an ignorant, fuperftitious, and fervilely debafed age?

To point out the real merit and character of this wonderful man, which is the purport of this paper, I thall now proceed to a review and general analyfis of his doctrines as ftated in his Opus Majus.

I truft it will be found to be an amazing extenfive plan, founded in experience of nature and on the analyfis of truth; conducted by the moft penetrating inventive faculties of induction, and the moft exact precifion of combination; that it is, as I faid before, a Reftauratio bumani intellectûs, and an Inftauratio fientice.

I. It firft ftates the caufes of error, and then clears the ground of them; difcards all pretenfions to knowledge which obtrude themfelves under the form of learning.

Sufficit nobis in inquifitione proprii intellectûs ut, quantum poffimus, caufas et occafiones erroris extraneas longius à debilitate fenfûs noftri religamus. Quatuor vero funt maxima comprehendendæ veritatis offendicula, quæ omnem quemcunque fapientem impediunt; et vix aliquem permittunt advorfùm titulum fapientiæ pervenire.

Imo. Fragilis et indignæe authoritatis exemplum.

Mark here the ground on which, in thofe days of ecclefiaftical and civil tyranny, the crime of herefy againt the church, and of treafon againft the ftate, might be imputed, and which was the real ground of his perfecution and imprifonment.

2do. Confuetudinis diuturnitas.

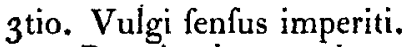

4to. Propriæ ignorantiæ occultatio cum oftentatione fapientiæ.

His omnis homo involvitur, onnis ftatus occupatur.

II. Thefe four points he examines, explains, and difcuffes fpecially and at full length under their feveral heads. The ground thus cleared, and the foundations thus laid, he proceeds in the fecond part in analyfing grammar to its elements; wherein he not only goes to the art of language, but to the powers and operations of the mind, by an inquifition into the human underftanding, as Mr. Locke, and Mr. Harris in his Hermes did afterward.

Then, paffing by the commonly received mode of reafoning, as it moves in the trammels of logic, which this great original ftates to be not only perverfive, but at beft a mere left-handed hold by which we take truths already difcovered; 
by which we lock them up in an artificial fyftem, and which is of no ufe or aid in the purfuit and the difcovery and invention of truth; he then treats of the virtue, power, and ufe of mathematics, properly fo called, both analytic in the inveftigation of truth, and fynthetic in conducting it to practical fcience.

4. By this conductor he goes firft through the inveftigation, and next through the didactive explanation and proof of the powers and operations of nature, by the principles of the laws of motion, attraction, gravity. Guided by thefe principles he proceeds to the laws of vifion, perfpective, and optics in general; and to the laws by which light is acted upon. And here he goes to the mechanical and inftrumental, fo as to explain the practical part, bringing forward many improved ufes and applications leading to new difcoveries.

5. He proceeds hence to aftronomy, in an inveftigation of the phænomena of the heavenly bodies. In this part fome remains of aftrological prejudices not yet eradicated obftruct his inftitute.

6. The heads above ftated take up five parts out of fix into which his Opus Majus is divided. He then, in the $f i t b$ part, comes to the main ground and true bafis on which the Inftauratio fcientice is founded and built up, which is experimental induction. This he explains in detail, and illuftrates by example; recurring again and again to the phænomena of nature terreftrial and celeftial :- * Duo funt modi cognofcendi, fcilicet, per argumentum et experimentum. Argumentum concludit, et facit concludere quæftionem; fed non certificat, neque removet dubitationem, ut quiefcat animus in intuitu veritatis, nifi eam inveniat viâ experientiæ.

Et quia hæc fcientia experimentalis à vulgo fudientium eft penitus ignorata, ideo non poffum perfuadere de ejus utilitate, nifi fimul ejus virtus et proprietas oftenduntur.

Whoever, divefted of preoccupation and prejudice as they fpring from the Confuetudinis + diuturnitas, and the fafcination of received fathion in thinking, reads this great work, with comparative reference to the Inftauratio fcientiarum of the fecond Bacon, the lord St. Albans, will find both works fimilarly grounded, and fimilarly conducted, as to the method and form; both alike built up on an inftitute of induction by experimental focience; both in the execution purfuing the fame line to the fame point; and muft conclude either, according to the old proverb, "tbat great wits jump;" or that the latter Bacon, although perhaps equally an original as the

* Cap. I and 2. partis 6tæ, de Scientia experimentali.

$\uparrow$ Explained in the fecond head of part $i$. 
firlt, had read and received a reflected ray of illumination from the works of the firt Bacon, our philofopher.

Thefe works of the monk had been buried, amidft the manufcripts of fuch learning as is never read, for three or four hundred years before the time in which the lord St. Albans wrote; and continued in the fame ftate for near a century after, to 1733 , when they were publifhed by the learned editor Dr. Jebb; yet they might not have efcaped the fcrutinizing, induftrious, inquifitive genius and informed ftudies of the fecond great philofopher. But let me here repeat, that whatever caufe or chance firft wrought this fecond great genius into operation, he was equally an original as the firft. For, whoever confiders the procefs of the operations of intellect, and the origin and progrefs of knowledge, will find it dificult, if not impoffible, to mark what that fpring, internal or external, is which firft becomes a caufe from a coincidence of ideas that gives courfe to it.

As it hath become an almoft generally received opinion, that the inftauration of true philofophy in the prefent age derives its fource primarily and folely from Bacon the lord St. Albans, I cannot but think it juft in this paper to endeavour to reftore to the firft original that portion of merit which is due to him; and fairly to appreciate the former, without derogating from the latter: and to recommend to this fociety to trace back the origin of their philofophy to a more remote fource, arifing within the bounds of the county in which this fociety is eltablifhed * from a fpring which, however illaudatus, unhonoured, and almoft loft in antiquity, will always be a peculiar honour to this county, as generally fo, in every extent and degree, to the Britioh nation at large.

Almoft all focieties, originally from fupertition, but fince from the habit of cuftom, have adopted fome fuppofed patron faint. Inftead of adopting a patron, let this fociety avow as their pattern the philofopher monk. Though no faint, it would be an honour to any philofophic fociety to adopt his principles, and to follow his example.

Ift, To adopt his principles by an independent fpirit of philofophizing, which will not be repreffed or kept down by the authority of any name howfoever great; will not be reftrained within the bounds of any fociety or fect howfoever refpectable; will not fubmit to any dominant lead, but, without oppofition or faction againft others, will unabated follow the fteps of truth with undeviating inveftigation; by an ar-

$$
\text { * Roger Bacon was born near Ilchefter. }
$$


dour which knows no repulfe, yet with an humility of diffdence which knows no prefumption.

$2 \mathrm{dly}$, By a temper which repels every tincture of fathion howfoever honoured by the times or confecrated by antiquity, confuetudinis diuturnitate.

3 dly, By a judgment which, whilft it refpeets the experience of mankind, defpifes the prejudices of the vulgar, great or fmall.

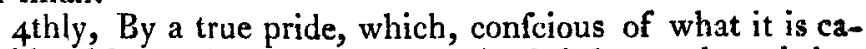
pable of, knows how to commence its firft fteps to knowledge, by feeling and acknowledging its ignorance; and not by a falfe thame attempting to hide it, and with a ftill more ridiculous vanity labouring to clothe it in the femblance and under the garb of learning. Of this tribe of learned gentlemen our monk fays, "Apparentia folùm tenet eos, non curant quid fciunt; fed quid videantur fcire coram multitudine infenfatâ."

Having thus adopted his principles, let us follow bis extample alfo in the mode of philofophizing; ift, By a patient induction and cautious combination of particulars, without being hafty to form them into fyftems on the firft tattering femblance of difcovery: $2 \mathrm{~d}$, That we do not fuborn affumed experiments to bear falfe witnefs to fuppofed facts; but to take more merit from the truth difcovered than from the difcovery; and to eradicate, if it be poffible, all vanity from the heart, et veritatem fine dote quarere.

Laftly, It will not be beyond the fcope of this paper, and, I would hope, not offenfive to this learned fociety, to fuggeft, whether amongt their other learned ftudies and philofophical refearches there may not be many a commenced, though interrupted, inftitute of experiments ; many a glimpfe of dircovery not yet brought out to open day in the works of this great original philofopher, well worth their attention for examination at leaft: yet

Non jurare in verba magifri.

I thall not here take notice of the difcovery of lenses, nor of their firft ufes in magnifying objects, and particularly as reading-glaffes; becaufe the refraction and reflection of light, and of the rays of the fun, by lenses and mirrors, were known to the antients *, though I do not meet with any mention of their ufe to aid in reading. But $I$ believe the antients wrote in fuch uncials as fuited the powers of the eye without this aid. Another reafon why I do not take notice of this as a difcovery to be imputed to Bacon is,

* Vide Scholiaft to the Nubes of Ariftophanes. 


\section{$33^{6}$ Fate and Cbaracter of the Monk Rogar Bacon.}

that he mentions the power and operations of glaffes on light, (if $I$ * remember and underftand him aright,) rather explaining thefe operations already in ufe, than as a difcovery made by himfelf. I think, however, that it is clearly a fact, that, like Sir Ifaac Newton, and like our Herfchel, the homour of the prefent age, he made thofe arrangements which produced the telefcope ; and that, like them, he applied his improvements to aftronomical obfervations. He particularly mentions a previntis trial which he made, as our common me. chanic opticians do, of reading fmall writing at a very great diftance.

I do not mention the difcovery of gunpowder as imputed to our monk, becaufe, although he + gives the mode of making this powder; and defcribes its explofive and corufcant power; and clearly points out that he had in his mind a deftructive ufe to which it might be applied in comburation, made to burn at a great diftance: yet he withholds himfelf from explaining this $u / e$; and does not in any part mention its explofion, as applied by the inflrumentality of tubes to a projectile force that was to throw the miffile weapons of cogles or balls. Which application of it renders it fpecifically gunpowder. His words are: "In omnem diftantiam, quam volumus, polfumus artificialiter componere ignem comburentem ex fale-petra et aliis." What thefe other articles are he mentions in another part of his works, namely, julpbur and cbarcoal.

I cannot reftrain myfelf from mentioning the idle traditional ftory of friar Bacon's brazen bead, which was to fpeak and announce time, becaufe $I$ think it founded in a real though miftaken fact. From confidering what one may elicit out of the nonfenfe of it, I have perfuaded myfelf that it was an experinent in horology, and the model of a clock meafuring time by the ofcillation of a pendulum, and by various movements in tbe face of this head, (as is actually the exifting fact in the clock at Bafle,) marking the divifions of time, together with a mechanifm that hould announce by found thofe divifions, which, in allufion to the face and bead, was called fpeaking; fimilar to the crowing of the cock on the clock at Strafbourg, or to the cuckoo on the wooden clocks which the Germans fell about our ftreets.

There remains fill to be mentioned, inconteftably to his unrivalled honour, that he was the firft difcoverer of the crror of meafuring fime by a falfe period of the year; and the firt projector of the reform of the calendar and other

* Removed from iny books, I quote from memory.

+ In his tra@t De Secretis Operibus Artis et Naruræ. 
tables of time, founded on his own aftronomical obfervations ; which reform he propofed to pope Clement V. It was the fate of this propofal to be neglected; whilft the imperfect Gregorian reckoning, which it hath been found neceffary fince to correct, was adopted. I will clofe this paper with a tranllation of the words of Dr. Jebb, the learned editor of the Opus Majus, as they ftand in his preface:-" The propofal made by Bacon to the pope Clement was one of the nobleft efforts of human induftry : confidered in all the circumftances under which it was framed and compofed, it is one of the moft ftupendous inftances of the force of human genius which hath been recorded; and will do honour to our learned countryman as long as the fun and moon endure."

LVII. Obfervations which feem to prove tbe Necelfity of ob. ferving and meditating a long Time before any decifive Opinion is formed in Pbilofopby in general, and particularly in regard to the Caufe of Eartbquakes. By Cou REJ OLLES*.

$\mathrm{H}_{0}$ DifOWER painful may be the refearches neceffary for difcovering the caufes which Nature employs in her operations, we muft obferve with great attention and indefatigable affiduity in order to collect thofe facts which are propereit for conducting us to the attainment of this object. It does not belong to men to invent caufes; they exift in nature, and it is their bufinefs to difcover them.

If in the exact fciences the precifion of a refult efcapes us, and if we cannot extend our conception but to that term where incommenfurability of dimenfions ftops calculation, how can the creators of fyttems pretend to the privilege of penetrating to the bottom of the abyffes where Nature has concealed her primitive caufes ? Nothing then but experience, obfervation, and comparifon, guided by geometrical method, can conduct us with wifdom in our refearches.

Senfible of this truth, I have thought it my duty to follow this progrefs in my obfervations on every thing that may relate to the caufe of earthquakes; for it would be imprudent to affign one before a variety of facts are eftablifhed. This method is the more certain, as Nature often fpontaneounly unveils herfelf : but a long time is neceffary to collect good obfervations: and we ought never to be precipitate in making them appear, becaufe in the ftudy of the fciences there is an age at which the paffions blind us by a too ardent defire

* From the Fournal de Pbviqque, Pluviore, an. 10.

You. XII. No. 48. 